\title{
LIKUIDITAS DAN PERMODALAN BANK MILIK PEMERINTAH SEBELUM DAN PADA MASA PANDEMI
}

\begin{tabular}{|c|c|c|c|}
\hline \multicolumn{4}{|c|}{ Nengah Sukendri } \\
\hline \multicolumn{4}{|c|}{ IAHN Gde Pudja Mataram, sukendri@stahn-gdepudja.ac.id } \\
\hline & & & \\
\hline $\begin{array}{l}\text { Dikirim tanggal } \\
\text { Revisi pertama tanggal }\end{array}$ & $\begin{array}{l}05 / 03 / 2021 \\
18 / 03 / 2021\end{array}$ & $\begin{array}{l}\text { Diterima tanggal } \\
\text { Tersedia online tanggal }\end{array}$ & $\begin{array}{l}20 / 03 / 2021 \\
25 / 03 / 2021\end{array}$ \\
\hline
\end{tabular}

\section{ABSTRACT}

This study analyzes state-owned Bank liquidity and capital before and during the Covid-19 pandemic in terms of liquidity and capital. The approach used in this research is comparative quantitative research. The data used are banking financial reports before and during the pandemic with a research focus: Bank Rakyat Indonesia (BRI), Bank Mandiri, Bank Negara Indonesia (BNI), Bank Tabungan Negara (BTN). Before the analysis was carrying out, the Research Instrument Prerequisite Test carrying out using Kolmogorov-Smirnov, and the analysis technique in this study was using paired ttest analysis. The results showed a difference before and during the pandemic regarding state-owned bank liquidity and capital adequacy.

Keyword: liquidity, capital, state-owned Bank

\begin{abstract}
ABSTRAK
Penelitian ini bertujuan untuk mendeskripsikan dan menganalisis Likuiditas dan Permodalan Bank Milik Pemerintah sebelum dan pada masa pandemi Covid-19 ditinjau dari likuiditas dan permodalan. Pendekatan yang digunakan dalam penelitian ini adalah penelitian kuantitatif komparatif. Data yang digunakan adalah laporan keuangan perbankan sebelum dan pada masa pandemi dengan fokus penelitian meliputi: Bank Rakyat Indonesia (BRI), Bank Mandiri, Bank Negara Indonesia (BNI), Bank Tabungan Negara (BTN). Sebelum dianalisis dilakukan Uji Prasayarat Instrumen Penelitian dengan menggunakan Kolmogrov Smirnov dan teknik analisis dalam penelitian ini menggunakan analisis uji t berpasangan (paired $t$ test). Hasil penelitian menjelaskan bahwa terjadi perbedaan sebelum dan pada masa terjadinya pandemi ditinjau dari segi likuiditas perbankan, dan dilihat dari segi kecukupan modal bank BUMN.
\end{abstract}

Kata Kunci: likuiditas, permodalan, BUMN 


\section{PENDAHULUAN}

Indonesia mengalami permasalahan wabah penyakit Covid-19 yang mengganggu seluruh aktivitas masyarakat Indonesia di seluruh aspek. Dalam id.wikipedia.org (2020), menjelaskan bahwa pandemi korona virus 2019-2020 atau dikenal sebagai pandemi Covid-19 adalah peristiwa menyebarnya penyakit korona virus 2019 (corona virus disease 2019) yang disingkat COVID-19 di seluruh dunia. Penyakit ini disebabkan oleh korona virus jenis baru yang diberi nama SARS-CoV-2. Wabah COVID-19 pertama kali dideteksi di kota Wuhan, Provinsi Hubei, Tiongkok pada bulan desember 2019 dan ditetapkan sebagai Pandemi oleh Organisasi Kesehatan Dunia (WHO) pada 11 Maret 2020. Hingga 28 Maret, lebih dari 620.000 kasus COVID-19 telah dilaporkan di lebih dari 190 negara dan teritori, mengakibatkan lebih dari 28.800 kematian dan 137.000 kesembuhan.

Langkah-langkah pencegahan yang direkomendasikan diantaranya mencuci tangan, menutup mulut saat batuk, menjaga jarak dari orang lain, serta pemantauan dan isolasi diri untuk orang yang mencurigai bahwa mereka terinfeksi. Pandemi ini telah menyebabkan gangguan sosioekonomi secara global. Salah satu yang berdampak adalah kondisi ekonomi. Pergerakan harga saham empat bank BUMN papan atas kompak menunjukkan penguatan di tanggal 14 April 2020 (www.indopremier.com). Tidak ada faktor khusus yang mendongkrak kenaikan harga empat bank BUMN tersebut selain kenaikan indeks harga saham gabungan (IHSG). Indeks berada pada level 4.688. Posisi ini menguat $1,34 \%$ atau 62 poin dibandingkan penutupan perdagangan terakhir. Berikut ini kenaikan harga saham sektor perbankan yang mendongkrak IHSG.

Tabel 1, Saham Bank yang Mengalami Kenaikan 14 April 2020

\begin{tabular}{|c|l|r|r|}
\hline No & \multicolumn{1}{|c|}{ Perusahaan } & Harga (Rp) & \multicolumn{1}{c|}{ Kenaikan (\%) } \\
\hline 1 & Bank Rakyat Indonesia & 2.870 & 3,6 \\
\hline 2 & Bank Mandiri & 4.630 & 3,8 \\
\hline 3 & Bank Negara Indonesia & 4.150 & 3,8 \\
\hline 4 & Bank Tabungan Negara & 975 & 6 \\
\hline
\end{tabular}

(www.indopremier.com)

Harga saham PT Bank Rakyat Indonesia Tbk (BBRI) saat ini berada pada level 2.870. Posisi ini menguat 100 poin atau 3,6\% dibandingkan penutupan perdagangan terakhir. Sementara harga saham PT Bank Mandiri Tbk (BMRI) berada pada level 4.630. Posisi ini menguat 170 poin atau 3,8\% dibandingkan penutupan perdagangan terakhir. Harga saham PT Bank Negara Indonesia Tbk (BBNI) berada pada level 4.150. Posisi ini menguat 150 poin atau 3,8\% dibandingkan penutupan perdagangan. Terakhir, harga saham PT Bank Tabungan Negara Tbk (BBTN) berada pada level 975. Posisi ini menguat 55 poin atau $6 \%$ dibandingkan penutupan perdagangan terakhir.

Tentunya dalam bidang perekonomian secara keseluruhan mengalami gangguan yang sangat signifikan dengan adanya kasus COVID 19. Namun yang menarik justru saham perusahaan perbankan terutama Bank BUMN sebagai pendongkrak utama IHSG 
yang berarti pasar dan investor justru menganggap adanya ketangguhan pada saham sektor perbankan terutama Bank BUMN. Ketangguhan Bank BUMN dapat diukur dengan berbagai indikator. Dalam hal ini, di bidang perbankan dalam menilai kesehatan bank dapat ditinjau dengan metode RGEC.

RGEC adalah factor risk profile (risiko bank), faktor Good Corporate Governance (GCG), faktor Earning (rentabilitas) dan faktor Capital (permodalan). Bank sebagai Lembaga yang menjadi perantara antara pihak penabung dan peminjam memiliki risiko yang sangat besar dan bermacam-macam seperti risiko pasar, risiko kredit macet, likuiditas dan lain sebagainya. Dalam penelitian ini, kita akan mengkaji lebih jauh terkait likuiditas dan permodalan. Kondisi COVID-19 ini menyebabkan perekonomian terganggu yang mengakibatkan banyaknya toko, swalayan, usaha, pariwisata yang tutup sehingga beberapa pengusaha yang terkena dampak ini melakukan restrukturisasi pinjaman di perbankan beberapa daerah di Indonesia. Dalam keuangan.kontan.co.id juga menjelaskan salah satu Bank BUMN yaitu BBTN (PT. Bank Tabungan Negara Tbk) dalam pengawasan OJK. Hasil dari penelitian ini dapat menjadi rekomendasi bagi investor untuk melakukan investasi di sektor perbankan di pasar modal dalam bentuk saham maupun obligasi di saat krisis. Selain itu bagi pemerintah harus memberi penguatan dan kebijakan pada sektor tertentu dalam rangka memberikan daya tahan disaat kondisi ekonomi belum normal. Secara khusus hasil ini memberi petunjuk bagi praktisi perbankan dalam mengambil keputusan berbagai kebijakan disaat krisis.

\section{Penelitian Yang Relevan}

Determinan permodalan bank melalui profitabilitas, risiko, ukuran perusahaan, efisiensi dan struktur aktiva. Penelitian ini menganalisis kausalitas antara CAR, profitabilitas, risiko, ukuran perusahaan, efisiensi dan struktur aset industri perbankan. Teknik sampling yang digunakan dalam penelitian ini adalah purposive sampling dengan kriteria bank telah go public sebelum 2008 dan menerbitkan laporan keuangan 2008-2013. Total sampel adalah 23 bank. Tujuan dari penelitian ini adalah untuk mengetahui pengaruh profitabilitas, risiko, ukuran perusahaan, efisiensi dan struktur modal dari aset bank. Teknik analisis yang digunakan adalah regresi linier berganda. Hasil penelitian menunjukkan bahwa profitabilitas, ukuran dan struktur aktiva memiliki dampak positif terhadap CAR. Sementara itu, risiko bank memiliki dampak negatif terhadap CAR. Efisiensi tidak berdampak pada CAR. Kontribusi penelitian ini untuk pengelolaan industri perbankan, peneliti dan regulator (Bank Indonesia) adalah bahwa ada suatu keharusan untuk meningkatkan rasio kecukupan modal dalam rangka meningkatkan daya saing perbankan nasional (Haryanto, 2016). Kontribusi dalam penelitian ini terkait permodalan dan perbankan.

Pengaruh good corporate governance terhadap kinerja keuangan dan nilai perusahaan (studi pada badan usaha milik negara (bumn) yang terdaftar di bursa efek Indonesia periode 2012-2015). Penelitian ini bertujuan untuk menganilisis dan menjelaskan pengaruh simultan dan dominan Good Corporate Governance yang terdiri dari variabel Dewan Komisaris Independen dan Komite Audit terhadap Kinerja Keuangan dan Nilai Perusahaan yang dihitung menggunakan Return on Assets dan Tobins ' $Q$. Hasilnya menunjukkan ada pengaruh signifikan secara simultan dari variabel 
Dewan Komisaris Independen dan Komite Audit terhadap Kinerja Keuangan, ada pengaruh signifikan secara simultan dari variabel Dewan Komisaris Independen dan Komite Audit terhadap Nilai Perusahaan. Secara parsial masing-masing variabel Good Corporate Governance berpengaruh signifikan terhadap Kinerja Keuangan dan Nilai Perusahaan. (Ferial et al., 2016). Kontribusi dalam penelitian ini yaitu terkait kinerja keuangan BUMN.

Pengaruh likuiditas, profitabilitas, dan solvabilitas terhadap harga saham (Studi Kasus pada Perusahaan Perbankan yang Terdaftar di Bursa Efek Indonesia). Penelitian ini bertujuan untuk memberikan bukti mengenai pengaruh likuiditas, profitabilitas dan solvabilitas perusahaan terhadap harga saham. Rasio-rasio keuangan yang diteliti yaitu Current Ratio, Return on Asset and Debt to Equity Ratio sebagai variabel independen dan harga saham sebagai variabel dependen. Jumlah sample yang digunakan dalam penelitian ini adalah perusahaan perbankan yang terdaftar pada BEI yang aktif diperdagangkan dari tahun 2011 sampai dengan 2015. Metode statistik yang digunakan adalah metode regresi berganda. Hasil penelitian ini menunjukkan bahwa variable rasio Current Ratio, Return on Asset and Debt to Equity Ratio secara statistik simultan berpengaruh signifikan untuk memprediksi harga saham yang akan diperdagangkan. Sedangkan secara statistik parsial variable Current Ratio dan Debt to Equity Ratio tidak berpengaruh sigifikan untuk memprediksi harga saham yang akan diperdagangkan di bursa (Octaviani \& Komalasarai, 2017). Persamaan dengan penelitian ini yaitu menganalisis likuiditas dan juga terkait perbankan.

Penelitian yang berjudul Analisis risiko likuiditas Perbankan Syariah di Indonesia bertujuan untuk mengetahui faktor-faktor yang mempengaruhi tingkat risiko likuiditas pada bank syariah. Faktor yang digunakan antara lain Return on Asset (ROA), Return on Equity (ROE), Capital Adequancy Ratio (CAR), Net Working Capital, dan Size of bank yang akan diujikan pengaruhnya terhadap Risiko likuiditas. Penelitian dilakukan dengan metode analisis regresi data panel (Panel Least Square) dan mengambil data sekunder masing-masing bank untuk periode 2012 hingga 2016 dengan sampel sebanyak 11 bank umum syariah di Indonesia. Analisis data dilakukan dengan menggunakan Eviews 7. Hasil penelitian menunjukkan bahwa ROE, CAR, dan Net Working Capital berpengaruh signifikan positif terhadap risiko likuiditas bank syariah. Sedangkan ROA dan Size of Bank berpengaruh signifikan terhadap risiko likuiditas bank syariah pada tingkat signifikansi 5\%. Penelitian ini mendukung penelitian sebelumnya yang dilakukan oleh Ahmad dan Mobin (2012), CAR dan Size of bank berpengaruh signifikan terhadap risiko likuiditas (Pratiwi, Sandy Anggur , Estiningtiastuti, 2016). Kontribusi dalam penelitian ini kaitannya dengan likuiditas perbankan.

Dalam penelitian Bank Perkreditan Rakyat (BPR) lembaga keuangan yang memiliki keterkaitan dengan pelaku Usaha Mikro Kecil dan Menengah (UMKM) yang tujuannya untuk mengetahui perubahan kinerja kredit terhadap profitabilitas, metode penelitian menggunakan deskriptif kualitatif, obyek penelitian BPR secara Nasional. Hasil penelitiannya menjelaskan bahwa pertumbuhan kredit BPR di masa pandemi COVID-19 pada akhir Agustus 2020, mengalami pertumbuhan walaupun tidak besar 1,28\%. Kinerja kualitas kredit BPR yang diukur dengan rasio NonPerforming Loan (NPL) juga terdampak pandemi COVID-19, akibatnya jumlah kredit non lancar 
semakin meningkat dan rasio NPL meningkat. Kurang optimalnya kinerja kredit dan meningkatnya rasio NPL, ditambah upaya penyelamatan kredit, berakibat menurunnya jumlah penerimaan dana kredit yang telah disalurkan kepada nasabah. Penerimaan dana angsuran kredit menurun dan tertunda, berdampak menurunnya pendapatan kredit dan secara keseluruhan berakibat pada kemampuan BPR memperoleh laba sebelum pajak. Hal ini menurunnya kinerja profitabilitas rasio ROA Agustus 2020 yaitu -16,02\% dibandingkan Desember 2019 (Wangsit Supeno, 2020). Persamaan dengan penelitian ini yaitu menganalisis kondisi perbankan di masa pandemi.

Penelitian dengan membandingkan kinerja Bank Perkreditan Rakyat Lumbung Kredit Pedesaan (BPR-LKP) di Nusa Tenggara Barat Sebelum dan Sesudah melakukan merger dan akuisisi yang berlangsung dari tahun 2009 sampai dengan 2011 (I. Putra, 2013). Pada saat itu terdapat 46 BPR LKP yang melakukan merger di provinsi tersebut dan bank yang melakukan merger/akuisisi adalah bank-bank kepemilikan pemerintah daerah baik prorvinsi maupun kabupaten/kota. Menggunakan 2 indikator untuk mengukur kinerja bank yaitu return on assets (ROA) untuk mengukur kemampulabaan bank dan indikator non performing loans (NPL) dalam mengukur pengawasan bank. Hasilnya cukup menarik yang didapatkan dari penelitian ini, justru setelah dilakukan merger dan akuisisi bahwa kondisi kinerja bank baik ditinjau dari profitabilitas maupun pengawasan menunjukan kondisi yang semakin tidak sehat dan hal ini disebabkan kondisi yang melakukan merger dan akuisisi adalah bank yang sedang menghadapi masalah terutama kredit bermasalah. Kontribusi dalam penelitian ini yaitu adanya persamaan analisis menggunakan uji beda dan terkait perbankan.

Penelitian yang menguji pengaruh kepemilikan manajerial terhadap likuiditas, biaya agensi, dan profitabilitas Credit Society Bank (CSB) di Provinsi Nusa Tenggara Barat, Indonesia yang menggunakan Partial Least Square (PLS). Hasil menunjukkan bahwa kepemilikan manajerial tidak berpengaruh terhadap likuiditas, biaya agensi dan keuangan kinerja. Tingkat likuiditas bank tidak mempengaruhi biaya agensi. Biaya agensi mempengaruhi negatif terhadap kinerja keuangan CSB, yang dapat diartikan semakin tinggi biaya keagenan bank, semakin rendah kinerja keuangan bank. Dalam hal ini, kontribusi penelitian ini terkait likuiditas perbankan dengan fokus penelitian yang berbeda.(Putra, INNA; Mannan,S.S.A;Gumanti,T.A; Sukendri, 2019). Sedangkan (I. N. N. A. Putra et al., 2020), terkait penelitian yang bertujuan untuk menganalisis variabel pengaruh kemampuan bayar dan kemampulabaan terhadap modal pada Bank Perkreditan Rakyat konvensional yang menggunakan alat analisis path analysis. Hasil penelitiannya menjelaskan bahwa secara keseluruhan kemampuan membayar berpengaruh negatif secara tidak langsung terhadap modal melalui kemampulabaan. Pengaruh negatif ini mengindikasikan adanya tingkat kemampuan bayar yang rendah namun melalui efisiensi dapat meningkatkan permodalan. Kontribusi dalam penelitian ini yaitu terkait permodalan perbankan. 


\section{Kerangka Penelitian}

Kerangka penelitian dalam penelitian ini dapat digambarkan sebagai berikut:

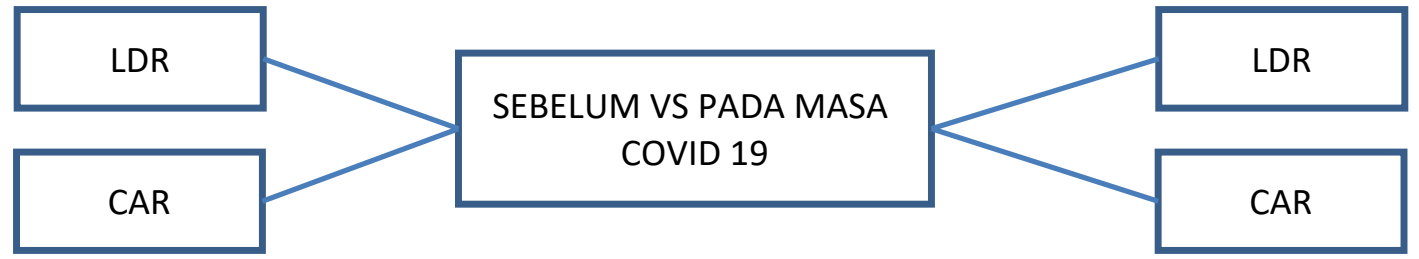

Gambar 2.1, Kerangka Penelitian

Gambar 2.1 menjelaskan bahwa kondisi saat ini Indonesia mengalami permasalahan wabah penyakit Covid-19 yang mengganggu seluruh aktivitas masyarakat Indonesia. Secara keseluruhan di bidang perekonomian mengalami gangguan, namun saham perusahaan perbankan terutama Bank BUMN sebagai pendongkrak utama IHSG yang berarti pasar dan investor justru menganggap adanya ketangguhan pada saham sektor perbankan terutama Bank BUMN. Dalam hal ini maka perlu dilakukan penelitian untuk mengetahui likuiditas dan permodalan bank milik pemerintah sebelum dan pada masa penyebaran virus covid-19 yang dapat diukur dengan berbagai indikator. Dalam penelitian ini menilai LDR dan CAR sebelum dan pada masa penyebaran virus covid 19.

\section{METODE PENELITIAN}

Jenis penelitian ini adalah penelitian kuantitatif komparatif yang berfokus pada kajian perbandingan mengenai kondisi BUMN di Indonesia sebelum dan pada masa adanya penyebaran virus terkait likuiditas dan permodalan sektor perbankan dalam menghadapi guncangan ekonomi global sebagai dampak adanya penyebaran virus atau pandemi Covid 19. Pendekatan yang digunakan adalah pendekatan kuantitatif karena menganalisis likuiditas dan permodalan bank BUMN dengan menggunakan data yang didasarkan pada annual report bank sebelum dan pada masa pandemi covid 19, yaitu 4 bulan sebelum dan 4 bulan setelah pandemi covid 19 terjadi di Indonesia. Penelitian ini menfokuskan pengujian likuiditas dan permodalan pada Bank Badan Usaha Milik Negara (BUMN), yaitu: Bank Rakyat Indonesia (BRI), Bank Mandiri, Bank Negara Indonesia (BNI), dan Bank Tabungan Negara (BTN). Jenis data yang digunakan dalam penelitian ini adalah data sekunder. Teknik analisis dalam penelitian ini merupakan uji komparatif yang berguna untuk menguji kemampuan generalisasi (signifikansi) hasil penelitian yang berupa perbandingan keadaan variabel dari dua rata-rata sampel berpasangan yaitu sebelum terjadi krisis dengan pada masa krisis Bank BUMN di Indonesia. 


\section{HASIL DAN PEMBAHASAN}

\section{Hasil Uji Prasayarat Instrumen Penelitian}

Data yang digunakan dalam penelitian ini berasal dari laporan keuangan 4 bank Badan Usaha Milik Negara (BUMN) yang ada di Indonesia. Data tersebut berupa rasio keuangan yang termasuk dalam skala data rasio karena berupa perbandingan antar elemen keuangan yang ada. Mengingat data tersebut rasio, maka sebelumnya harus dilakukan uji normalitas data sebelum diolah lebih lanjut. Uji normalitas data salah satunya dapat dilakukan dengan uji satu sampel kolmogorov-smirnov. Hasil uji kolmogorov-smirnov data keuangan tersebut nampak pada tabel 4.1 berikut.

Tabel 2. Uji Normalitas Data

\begin{tabular}{|l|l|r|r|r|r|}
\hline \multicolumn{2}{|c|}{} & \multicolumn{1}{|c|}{ LDR_B } & \multicolumn{1}{|c|}{ CAR_B } & \multicolumn{1}{c|}{ LDR_A } & \multicolumn{1}{c|}{ CAR_A } \\
\hline $\mathrm{N}$ & 16 & 16 & 16 & 16 \\
\hline \multirow{2}{*}{$\begin{array}{l}\text { Normal } \\
\text { Parameters }{ }^{\mathrm{a}, \mathrm{b}}\end{array}$} & Mean & .975908300313 & .908756603125 & .937261650938 & .791229757750 \\
\cline { 2 - 7 } $\begin{array}{l}\text { Most Extreme } \\
\text { Differences }\end{array}$ & Std. Deviation & .0863687847000 & .2688147476446 & .0909915486364 & .2396067899351 \\
\cline { 2 - 7 } & Absolute & .268 & .265 & .258 & .325 \\
\cline { 2 - 7 } & Positive & .268 & .148 & .258 & .190 \\
\hline Kolmogorov-Smirnov Z & -.150 & -.265 & -.162 & -.325 \\
\hline \multicolumn{7}{|l|}{ Asymp. Sig. (2-tailed) } & 1.071 & 1.058 & 1.033 & 1.301 \\
\hline a. Test distribution is Normal. & .202 & .213 & .236 & .068 \\
\hline b. Calculated from data. & \multicolumn{5}{|l}{} \\
\hline
\end{tabular}

Berdasarkan hasil pada Tabel 2 tersebut data normal terlihat pada variabel LIKUIDITAS dan MODAL pada kondisi sebelum pandemi COVID-19, maupun pada masa pandemi ternyata berdistribusi normal. Data normal dapat diidentifikasi melalui nilai signifikansi yang berada di atas nilai 0.05 menunjukan bahwa data berdistribusi normal yaitu 0.202 dan 0.213 untuk sebelum pandemi dan pada masa pandemi 0.236 dan 0.068 .

Nilai signifikansi hasil uji Kolmogorov-smirnov menunjukan nilai 0,038 untuk sebelum terjadinya covid-19 dan 0,538 setelah pada masa terjadinya penyebaran virus corona. Melihat kondisi data yang secara keseluruhan baik sebelum maupun pada masa pandemi hanya variabel LIKUIDITAS dan MODAL yang berdistribusi normal, maka dapat diperbanndingkan menggunakan alat analisis uji-t 2 sampel berpasangan. Uji normalitas merupakan uji asumsi dasar yang harus dipenuhi data yang dianalisis pada data kontinyu (interval dan rasio) yang akan melakukan uji statistik parametrik.

\section{Hasil Analisis Data}

Berdasarkan hasil uji normalitas data dengan metode uji 1 sampel Kolmogorovsmirnov, secara keseluruhan variabel yang memiliki data normal. Artinya pengujian uji beda dengan menggunakan uji-t berpasangan atau berhubungan dapat dilaksanakan. Pengujian ketiga varibel yang memiliki normalitas data nampak pada tabel 3 sebagai berikut. 
Tabel 3. Hasil Uji t Berpasangan

\begin{tabular}{|c|c|c|c|c|c|c|c|c|c|}
\hline & \multicolumn{5}{|c|}{ Paired Differences } & \multirow{3}{*}{$\mathbf{T}$} & \multirow{3}{*}{ Df } & \multirow{3}{*}{ 象 } \\
\hline & & \multirow[t]{2}{*}{ Mean } & \multirow{2}{*}{$\begin{array}{c}\text { Std. } \\
\text { Deviation }\end{array}$} & \multirow{2}{*}{$\begin{array}{l}\text { Std. Error } \\
\text { Mean }\end{array}$} & \multicolumn{2}{|c|}{$\begin{array}{c}95 \% \text { Confidence Interval of } \\
\text { the Difference }\end{array}$} & & & \\
\hline & & & & & Lower & Upper & & & \\
\hline Pair 1 & $\begin{array}{l}\text { LDR_B - } \\
\text { LDR_A }\end{array}$ & $\begin{array}{r}.038646649 \\
3750\end{array}$ & $\begin{array}{r}.0477503196 \\
461\end{array}$ & $\begin{array}{r}.0119375799 \\
115\end{array}$ & $\begin{array}{r}.0132023000 \\
975\end{array}$ & $\begin{array}{r}.064090998 \\
6525\end{array}$ & 3.237 & 15 & .006 \\
\hline Pair 2 & $\begin{array}{l}\text { CAR_B - } \\
\text { CAR_A }\end{array}$ & $\begin{array}{r}.117526845 \\
3750\end{array}$ & $\begin{array}{r}.0620974219 \\
732\end{array}$ & $\begin{array}{r}.0155243554 \\
933\end{array}$ & $\begin{array}{r}.0844374649 \\
137\end{array}$ & $\begin{array}{r}.150616225 \\
8363\end{array}$ & 7.570 & 15 & .000 \\
\hline
\end{tabular}

Kedua variabel yang memiliki data normal yaitu likuiditas dan modal dilakukan uji t 2 sampel berpasangan. Hasil pada Tabel 3 tersebut merekomendasikan bahwa ada perbedaan likuiditas bank BUMN sebelum dan pada masa terjadinya pandemi covid-19 di Indonesia. Secara keseluruhan nampak bahwa terjadinya penyebaran virus corona atau pandemi covid-19 di Indonesia memang berdampak pada perekonomian secara global. Penyebaran yang begitu cepat tersebut sangat dirasakan oleh seluruh masyarakat dan dunia bisnis. Perlu dicermati bahwa hasil penelitian secara keseluruhan menunjukkan likuiditas dan permodalan dalam hal ini Bank milik Badan Usaha milik Negara (BUMN) terjadi perbedaan sebelum dan pada masa pandemi pada tingkat likuiditas dan modal bank BUMN di Indonesia.

\section{Pembahasan}

Berdasarkan hasil analisis data yang dilakukan pada bank-bank BUMN yang ada di Indonesia, maka dapat dijelaskan perbedaan likuiditas dan permodalan sektor perbankan yang dimiliki BUMN.

\section{Perbedaan ditinjau dari likuiditas}

Pengelolaan likuiditas merupakan salah satu aktivitas penting yang dilaksanakan bank. Jadi, bank harus mengidentifikasi setiap transaksi finansial yang mempunyai implikasi terhadap likuiditas bank dan memelihara kondisi likuiditas secara hati-hati (BARA dan LSPP;2010). Hasil uji beda bank BUMN ditinjau dari likuiditas ternyata menunjukkan terjadinya perbedaan sebelum dan pada masa di era pandemi. Kondisi likuiditas sebelum penyebaran virus covid-19 ditunjukan dengan nilai rata-rata penurunan LDR dari 97,5\% sebelum terjadinya penyebaran virus menjadi $93,7 \%$ di era pandemi. Jelaslah ada perbedaan antara sebelum dan pada masa terjadinya pandemi dan akibat adanya pandemi tersebut likuiditas dari bank BUMN menurun. Turunnya kemampuan memberikan kredit ini disebabkan kondisi perekonomian yang tidak berjalan dengan normal sehingga kemampuan masyarakat dalam mengakses kredit yang diberikan pihak perbankan semakin menurun. Hal tersebut sangat dipengaruhi $5 \mathrm{C}$ dalam pemberian kredit yaitu Character, Colateral, Capital, Capacity dan Condition. Kelima hal tersebut, faktor Condition dan Capacity punya peran yang besar dalam penurunan nilai pemberian kredit. Faktor Condition atau kondisi ekonomi sangat terpengaruh dengan adanya pembatasan berbagai aktivitas termasuk dalam dunia bisnis.

Penyebaran virus yang cepat memaksa pemerintah untuk memberlakukan Pembatasan Sosial Berskala Besar (PSBB) dan Work from Home (WFH). Hal tersebut bertendensi menimbulkan inflasi dan menurunkan pertumbuhan ekonomi. Tentu saja 
faktor ekonomi yang tak menentu tersebut juga berdampak pada menurunnya penghasilan warga masyarakat yang mendapatkan uang dari adanya interaksi orang per orang seperti contohnya jasa transportasi. Sektor ini mau tidak mau mengalami penurunan yang tajam karena kebanyakan orang melaksanakan kegiatan dari rumah dan lebih memilih menggunakan jasa ojek online untuk pembelian barang dan pengiriman barang.

Nilai Kredit yang yang turun dibarengi pula dengan meningkatnya jumlah simpanan masyarakat di bank. Hal tersebut karena tingkat suku Bunga yang mengalami kenaikan. Beberapa saat yang lalu akhirnya pemerintah melakukan penurunan tingkat suku bunga. Harapannya agar masyarakat dapat mengakses kredit dengan angsuran yang lebih ringan di masa pandemi. Melalui penurunan suku bunga ini mengakibatkan nilai LDR yang tadinya terjun bebas agak sedikit bisa di rem laju penurunannya. Hal tersebut terlihat pasca pandemi penurunan LDR masih diatas ambang batas normal LDR yaitu $89 \%$. Artinya walaupun terjadi penurunan likuiditas pada bank BUMN namun penurunan tersebut masih dalam kategori sehat. Hal tersebut menunjukkan ketangguhan sektor perbankan terutama pada bank BUMN di Indonesia.

\section{Perbedaan ditinjau dari permodalan}

Pengelolaan modal bank harus memiliki komposisi yang sehat sesuai dengan tujuan strategis bank untuk mengatsasi risiko dari aktivitas bank (Rambey, 2012). Dalam penelitian ini mengevaluasi modal bank yaitu dengan CAR (Capital Adequacy Ratio), yaitu membandingkan antara modal terhadap aktiva tertimbang menurut risiko (Kasmir,2010). Hasil penelitian ini, ada perbedaan permodalan sebelum dan pada masa terjadinya penyebaran virus corona. Hal tersebut dapat kita lihat dari rata-rata permodalan sebelum adalah sebesar $90,8 \%$ dan pada masa terjadinya $79,12 \%$ yang berarti memang terjadi penurunan modal yang cukup signifikan sebelum dan pada masa mewabahnya virus corona. Wabah yang masuk ke Indonesia awal bulan Maret tahun 2020 tersebut menyebabkan turunnya modal inti dan modal pelengkap perusahaan perbankan $11,68 \%$. Hal yang cukup menenangkan sektor perbankan, karena penurunan ini masih di atas standar kecukupan permodalan yaitu $8 \%$.

Perbedaan sebelum dan pada masa wabah yang terjadi ditinjau dari permodalan perbankan disebabkan oleh beberapa hal misalnya kenaikan nilai ATMR atau aktiva tertimbang menurut risiko. Kenaikan ATMR ini dipicu oleh asset yang dimiliki pihak bank BUMN cenderung meningkat seperti Giro, Tabungan dan simpanan berjangka. Bobot dari ketiga bentuk dana pihak ketiga ini adalah 20\%. Tingkat suku bunga sebelum terjadinya penyebaran wabah covid yang lebih tinggi menyebabkan rata-rata nilai permodalan sebelum pandemi menjadi lebih tinggi. Adanya ketidakpastian ekonomi atau kelesuan pertumbuhan ekonomi merangsang masyarakat untuk menyimpan dananya dalam giro tabungan dan simpanan berjangka pasca pandemi, sehingga dampaknya peningkatan giro, tabungan dan simpanan berjangka pasca penyebaran virus corona. Besarnya nilai ATMR oleh simpanan dana pihak ketiga ini tentu akan menurunkan nilai CAR (capital adequacy ratio) yang tadinya sebesar $90,8 \%$ menjadi 79,12\%. Dalam hal ini, penurunan nilai persentase CAR ini masih diatas standar yang ditentukan pihak yang berwenang. 


\section{KESIMPULAN DAN SARAN}

Berdasarkan hasil dan pembahasan maka dapat dirumuskan simpulan sebagai berikut: terjadi perbedaan sebelum dan pada masa terjadinya wabah covid-19 ditinjau dari segi likuiditas perbankan. Kondisi likuiditas sebelum penyebaran virus covid-19 ditunjukkan dengan nilai rata-rata penurunan LDR dari 97,5\% sebelum terjadinya penyebaran virus menjadi $93,7 \%$ di era pandemi. Perbedaan tersebut tenyata diperkuat karena menurunnya faktor condition (kondisi ekonomi) atau terjadinya penurunan pertumbuhan ekonomi. Hal tersebut tentu juga menyebabkan menurunnya daya beli/bayar (capacity) dari debitur yang meminjam uang pasca wabah covid-19. Dilihat dari segi kecukupan modal bank BUMN, ada perbedaan pada masa pandemi yang disebabkan oleh meningkatnya dana pihak ketiga yang disimpan di bank BUMN semakin meningkat terbukti dari rata-rata permodalan sebelum adalah sebesar $90,8 \%$ dan pada masa terjadinya $79,12 \%$ yang berarti memang terjadi penurunan modal yang cukup signifikan sebelum dan pada masa mewabahnya virus corona. Hal tersebut terjadi karena adanya ketidakpastian ekonomi dan investasi. Ada kecenderungan masyarakat untuk menyimpan dananya kepada bank dalam bentuk giro, tabungan dan deposito.

\section{DAFTAR PUSTAKA}

Anonim. 2020. Harga Saham Bank BUMN Papan Atas Kompak Menguat. https://www.indopremier.com/ipotnews/newsDetail.php?jdl=HargaSaham_Bank BUMN_Papan_Atas_Kompak_Menguat\&news_id=118157\&group_news=IPOT NEWS\&taging_subtype $=\mathrm{PG} 002 \&$ name $=\&$ search $=\mathrm{y} \_$general $\& \mathrm{q}=, \&$ halaman $=1$.

Anonim. 2020. Pandemi koronavirus 2019-2020. https://id.wikipedia.org/wiki/ Pandemi_koronavirus_2019\%E2\%80\%932020.

Anonim. 2020. Bank Umumkan nama-nama Bank terkait pengawasan OJK, BPK: Kami punya wewenang. https://keuangan.kontan.co.id/news/umumkan-nama-namabank-terkait-pengawasan-ojk-bpk-kami-punya-wewenang/?page=all

Banker Association for Risk Management (BARa) dan Lembaga Sertifikasi Profesi Perbankan (LSPP). 2010. Modul Level 1, Edisi Kedua, Jakarta.

Ferial, F., Suhadak, S., \& Handayani, S. (2016). PENGARUH GOOD CORPORATE GOVERNANCE TERHADAP KINERJA KEUANGAN DAN EFEKNYA TERHADAP NILAI PERUSAHAAN (Studi Pada Badan Usaha Milik Negara yang Terdaftar di Bursa Efek Indonesia Periode 2012-2014). Jurnal Administrasi Bisnis S1 Universitas Brawijaya, 33(1), 146-153.

Haryanto, S. (2016). Determinan Permodalan Bank Melalui Profitabilitas, Risiko, Ukuran Perusahaan, Efisiensi Dan Struktur Aktiva. Jurnal Ekonomi Dan Bisnis, 18(1), 117. https://doi.org/10.24914/jeb.v19i1.483

Kasmir. 2010. Manajemen Perbankan. Divisi Buku Perguruan Tinggi, PT. 
RajaGrafindo Persada, Jakarta.

Mathew, N.G., dan L.A. Esther. 2012. A Financial Performance Comparison of Foreign VS Local Banks in Ghana, International Journal of Business and Social Science, Vol. 3 No. 21, pp. 82-87.

Octaviani, S., \& Komalasarai, D. (2017). PENGARUH LIKUIDITAS, PROFITABILITAS, dan SOLVABILITAS TERHADAP HARGA SAHAM (Studi Kasus pada Perusahaan Perbankan yang Terdaftar di Bursa Efek Indonesia). Jurnal Akuntansi., 3(2), 77-89.

Pratiwi, Sandy Anggur, Estiningtiastuti, P. T. (2016). Analisis Risiko Likuiditas Perbankan Syariah di Indonesia. Ekonomic, 2012, h.7-8.

Putra, INNA; Mannan,S.S.A;Gumanti,T.A; Sukendri, N. (2019). THE EFFECT OF MANAGERIAL OWNERSHIP ON LIQUIDITY, AGENCY COST AND PERFORMANCE OF CREDIT SOCIETY BANKS IN WEST NUSA TENGGARA PROVINCE OF INDONESIA. Business Innovation and Development in Emerging Economies: Proceedings of the 5th Sebelas Maret International Conference on Business, Economics and Social Sciences (SMICBES 2018), July 17-19, 2018, Bali, Indonesia.

Putra, I. (2013). PERBEDAAN PROFITABILITAS DAN TINGKAT PENGAWASAN SEBELUM DAN SESUDAH MERGER PADA BANK PERKREDITAN RAKYAT. Jurnal Keuangan Dan Perbankan, Vol.17, No.2 Mei 2013, Hlm. 302309.

Putra, I. N. N. A., Gede, M. I., Gde, B. I. D., \& Hery, S. (2020). BANK PERKREDITAN RAKYAT Jurnal Magister Manajemen Unram. 9(3), 286-294.

Rambey, S.. 2012. Workshop on: Indonesia Certificate in Banking Risk and Regulation Level 2, Module 1, School of Banking and Finance.

Wangsit Supeno, I. H. (2020). Kinerja Kredit Terhadap Profitabilitas Bpr Pada Masa Pandemi Covid-19. Journal of Chemical Information and Modeling, 53(9), 16891699. 